\title{
The Importance of Local Investments Co-Financed by the European Union in the Field of Renewable Energy Sources in Rural Areas of Poland
}

\author{
Aldona Standar ${ }^{1, *(D)}$, Agnieszka Kozera ${ }^{2}(D)$ and Łukasz Satoła ${ }^{3}(\mathbb{D}$ \\ 1 Department of Economics and Economic Policy in Agribusiness, Poznań University of Life Sciences, \\ Wojska Polskiego 28, 60-637 Poznań, Poland \\ 2 Department of Finance and Accounting, Poznań University of Life Sciences, Wojska Polskiego 28, \\ 60-637 Poznań, Poland; agnieszka.kozera@up.poznan.pl \\ 3 Department of Management and Economics of Enterprises, University of Agriculture in Krakow, \\ al. Mickiewicza 21, 31-120 Kraków, Poland; lukasz.satola@urk.edu.pl \\ * Correspondence: standar@up.poznan.pl
}

Citation: Standar, A.; Kozera, A.; Satoła, $€$. The Importance of Local Investments Co-Financed by the European Union in the Field of Renewable Energy Sources in Rural Areas of Poland. Energies 2021, 14, 450. https://doi.org/10.3390/ en14020450

Received: 22 December 2020

Accepted: 12 January 2021

Published: 15 January 2021

Publisher's Note: MDPI stays neutral with regard to jurisdictional claims in published maps and institutional affiliations.

Copyright: (c) 2021 by the authors. Licensee MDPI, Basel, Switzerland. This article is an open access article distributed under the terms and conditions of the Creative Commons Attribution (CC BY) license (https:// creativecommons.org/licenses/by/ $4.0 /)$.

\begin{abstract}
Local investments for the development of renewable energy sources (RESs) constitute an important element of sustainable rural development. They are conducive to the social and economic development of the said areas, and improve the environmental values and living conditions of their inhabitants. However, such advancement in rural areas is not possible without adequate financial support, including the funds from the EU budget. Therefore, the main objective of the research is to assess the scale, scope and importance of local investments in renewable energy sources in rural areas of Poland in 2014-2020, cofinanced from EU funds. The study covered 1117 projects, whose beneficiaries were rural and urban-rural municipalities. Evaluation of the municipal investment activities in acquiring EU subsidies in the area of environmentally friendly energy was conducted using selected methods of descriptive statistics and the analysis of variance. Subsequently, with the use of logistic regression, the study identified the main socioeconomic, financial and environmental conditions of the investment activities of the local government entities in RES in rural areas. Empirical studies allowed for the positive verification of the research hypothesis, which assumed that "The highest investment activity in the field of local projects co-financed from EU funds, related to the development of RES in rural areas, may be attributed to municipalities performing primarily agricultural functions, located in Eastern Poland". The municipalities' own income potential and investment activity are of major importance for the acquisition of EU funds used in RES financing. Municipalities at a lower development level demonstrated a greater activity in accessing these funds. They view the development of RES as an opportunity for accelerated growth.
\end{abstract}

Keywords: local investments; renewable energy sources; municipal economy; EU funds; rural areas; Poland

\section{Introduction}

In recent years, particularly after Poland's accession to the European Union (EU), a considerable amount of attention has been given to perspectives and threats of the rural development, especially in the context of their sustainable development [1]. In Poland, rural areas cover more than $90 \%$ of the country's area [2] and are characterized by a significant degree of developmental diversity, particularly at the municipal level [3-6]. The widely discussed issues of sustainable rural development cover many problems, such as activities aimed at rationalizing the management of natural resources [7,8], local development planning and protection of the environmental values of these areas [9]. The use of renewable energy sources (RESs) may improve the quality of the natural environment in rural areas [10]. According to the Energy Law Act, RES are "the sources which, in the course of energy processing, use wind power, solar power, geothermal energy, sea waves, 
sea currents and tidal energy, or energy acquired from the fall of rivers, and biomass energy, energy from landfill biogas and biogas produced in the process of sewage disposal and treatment, or decomposition of plant and animal remains" [11]. Renewable sources of energy constitute an alternative to fossil fuels and contribute to the reduction of greenhouse gas emissions [12], the diversification of energy supplies and decrease of dependence on uncertain and unstable fossil fuel markets, particularly oil and gas [13]. However, it is worth noting that the development of RES has to be coordinated with other actions that improve the energy efficiency of the economy. Without taking such actions, a phenomenon known in economic literature as the Jevons paradox may occur. In his research, Jevons has shown that technical change related to increased efficiency of use of a given resource usually leads to increased resource consumption [14-16]. The economic development level of a country is also a vital aspect. In the early stage of development, economic growth processes are accelerated at the expense of high resource consumption and, consequently, environmental pollution. After a certain economic development level is exceeded, the so-called turning point occurs and the environmental protection expenditures start to grow. This dependence in relation to wealth and income inequality was spotted by Kuznets. Next, it was adapted to environmental and natural resource economics [17,18]. The use of renewable energy resources without taking any other actions aimed at social and economic development may turn out to be another unsustainable strategy [19].

The policy of the European Union with regard to RES is unambiguous-European economy is to strive to reduce carbon dioxide emissions, which is evidently related to the development of RES [20,21]. Efficient use of energy, and human, economic and natural resources, constitute a fundamental principle of sustainable energy development (SED) [22] The Green Deal initiative, too, includes measures taken to ensure a better resource efficiency through the transition to a clean circular economy and the reduction of pollution levels. These goals are supposed to be attained through measures, which include investments in state-of-the-art environmentally friendly technologies. Hence, this paper contributes to research on the allocation of EU funds to RES. Already in early 2021, the Commission will adopt a new, more ambitious EU strategy for accommodating climate change in order to intensify its security measures against climate change. Fighting against climate change and attaining climate neutrality will require considerable investments and collective measures. Hence, it is important to investigate on financial resources allocated to these goals [23].

In Poland, rural areas exhibit significant potential for RES development. This is indicated by considerable biomass resources, roof surfaces, watercourses and areas unsuitable for agricultural activity. In rural areas, the investments in RES may have an important economic and social function [10]. RESs exhibit potential for the improvement of living conditions, environmental quality and conducting various types of activities in peripheral areas (e.g., in rural areas of Eastern Poland) and constitute an additional source of income of the population [24]. However, in order to develop RES in rural areas, it is necessary to acquire appropriate financial support. An important role in the construction of green energy installations is given to local investments of basic territorial units (local self-government units) in Poland, i.e., municipalities that use means from various EU funds for this purpose [25].

The main objective of the research is to assess the scale, scope and importance of local investments in renewable energy sources in rural areas of Poland in 2014-2020, cofinanced from EU funds. The empirical studies aimed at verification of the research hypothesis, which assumed that "The highest investment activity in the field of local projects co-financed from EU funds, related to the development of RES in rural areas, may be attributed to municipalities performing primarily agricultural functions, located in Eastern Poland". 


\section{Literature Review}

2.1. Financing Investments in Energy from RES—Strategic Assumptions of the European Union and Poland

The energy sector constitutes one of the most relevant economic sectors in every country [26]. Its key importance results from the role that energy has in the functioning of modern society and economies. The ability to produce energy in sufficient volume to satisfy the current and future demand of domestic recipients becomes a fundamental dimension of energy security. Energy security is currently considered one of the main areas of the state, and the national economy security, which to a certain extent proves the country's independence [27].

Local self-government units conduct a number of tasks aimed at improving the living standard of their inhabitants, and ensuring the dynamics of local development. Within the responsibilities of municipal management, apart from the basic tasks (related to, e.g., the supply of water and sewage disposal) recently, there is also increasing emphasis on the supply of electricity, heat and gas [28,29]. For many years, the organizational and legal solutions adopted in Poland have consolidated the significant role of large concerns from the energy and fuel sectors in providing energy carriers (electricity and natural gas).

The currently arising development challenges, and the necessity to undertake actions involving the requirements of the environmental protection and sustainable development result, among other things, in a significantly increased interest in unconventional, renewable energy sources. Due to a much greater dispersion of RES compared to non-renewable sources, primarily from fossil fuels, the problem of their decentralized production is becoming a topical issue [30]. Combined with the decentralized energy demand represented by households and business entities, the role of local self-government units is substantially rising and will continue to do so in the future [31]. They are the ones who, having the best recognition of local conditions and needs, are the most inclined to become an important part of the energy market. According to Charles Tiebout's theory (decentralization hypothesis), local goods and services should be delivered in a decentralized manner, at the lowest level of territorial division, which ensures the economic efficiency of this process [32].

The presented conditions prove that the relevance of municipalities (the basic entities of the local self-government sector in Poland) as entities participating in the energy distribution is increasing. Moreover, their role may be considered in a twofold manner. Firstly, as entities capable of participating in the generation and distribution of energy obtained from renewable sources by themselves or through their subsidiaries, e.g., municipal enterprises. In the latter case, municipalities may participate, as a consultative body, in the efforts of their inhabitants or entrepreneurs in acquiring funds for the implementation of investments related to the use of renewable energy sources.

The processes of dynamic economic development, occurring in most countries in the world, results in a significant increase in energy demand. This increase, and the consequent rise in the consumption of energy substrates, is also associated with a rising number of population and improved standard of living $[33,34]$. The model of economic growth that was present for many years, resulted in overexploitation of natural resources and environmental pollution. It was noted that, due to the depletion of resources, it is not possible to proceed with this model. Currently, many countries, especially in the $\mathrm{EU}$, are taking actions aiming at ensuring environmental protection and more sustainable development, which refer to the environmental Kuznets curve [35,36]. The increase in economic energy consumption may result in the insufficiency of conventional energy sources in meeting global energy demand [37]. However, it is worth noting that the exploitation of renewable energy sources alone, without taking any other actions aimed at improving energy efficiency will be insufficient. As, according to Jevons paradox, the emergence of new energy sources leads to increased exploitation of these resources. Therefore, it is necessary to take measures to reduce energy consumption and increase energy efficiency in the economies of many countries around the world [38,39]. 
As, according to Jevons paradox, the emergence of new energy sources leads to increased exploitation of these resources. Therefore, it is necessary to take measures to reduce energy consumption and increase energy efficiency in the economies of many countries around the world $[38,39]$. In Poland, most of the energy is produced as a result of the coal combustion, which, apart from the natural issues related to the depletion of coal resources, generates significant problems in terms of air pollution and environmental protection. There is also the problem of the country fulfilling its commitments, related to the agreements with the European Union, which Poland ratified. The absence or insufficient reduction of pollutants generated in the production of electricity may result in the imposition of high penalties on entities that do not meet the environmental requirements. An excessive greenhouse gas emission constitutes a continuous problem for the Polish energy sector [40].

One of the methods that reduce the emission of harmful substances into the atmosphere is to implement the idea of a low emission economy (cf. [41]). It involves all actions aimed at reducing greenhouse gas emissions while respecting the principles of sustainable development that consider competitiveness and innovativeness in the global market [42]. Documents of the European Commission state that the transition to a competitive, lowcarbon economy would indicate that by 2050, the European Union should reduce emissions by $80 \%$ compared to their 1990 levels [21]. The implementation of the low-carbon economy is thus one of the key problems that the economies of the EU Member States encounter. The transition of the EU economy, particularly the energy supply sector, to one that would fulfill the low-carbon economy postulates is an important and a topical challenge. In order to address this challenge, high costs would have to be borne by both the private and public sectors [43]. Its importance is further increased in conditions of rising air pollution and consequent climate changes [44].

The process of energy production from conventional sources results in a high amount of pollution being introduced into the water and atmosphere. This is one of the reasons why many countries around the world and within the EU are undertaking steps to minimize pollution and promote alternative solutions for unconventional energy sources. Due to the importance of climate change and the depletion of conventional sources, such actions are supported institutionally. Support programs for various undertakings fulfilling the postulates of a low-carbon economy are implemented at the level of the European Union, individual Member States and local self-government units. The basic EU document that determines the direction of necessary actions related to changes in energy production is the climate and energy package. Until 2030, the Climate and Energy Policy includes common, EU assumptions and objectives for 2021-2030. In the 2030 perspective, the most important ones include $[45,46]$ :

- Reducing a minimum of $40 \%$ of greenhouse gas emissions (compared to 1990 levels),

- Increasing the share of energy from renewable sources in the total energy consumption to a minimum of $32 \%$,

- Increasing energy efficiency by a minimum of $32.5 \%$.

The basic assumptions of the Climate and Energy Policy were adopted by the European Council in 2014, while the RES and energy efficiency objectives were increased in 2018. The revision of the objectives, including the increase of RES requirements, clearly indicates that, to a large extent, the EU associated their development with an opportunity to reduce the emission of harmful substances into the atmosphere and the negative impact on climate change.

\subsection{Opportunities and Threats for the Development of RES Energy Related to the Use of Resources in Rural Areas}

In Poland, the production of energy from renewable sources is based primarily on biofuels, which account for its $80 \%$. Wind power also has a significant share $(12 \%)$, while much less energy is generated from biogas $(2.9 \%)$, water $(2 \%)$, and solar energy $(0.7 \%)$. 
Insignificant amounts of energy are produced from geothermal sources, heat pumps and municipal waste incineration [47,48].

Decisions made at the EU level result in an increased interest in energy from renewable sources, i.e., energy generated from water, biomass, wind, solar radiation and geothermal sources. The advantage of renewable energy sources over conventional ones consists in their availability in unlimited quantities, the fact that they do not, or emit a small amount of greenhouse gases, and their higher level of affordability. The rising awareness of the population in the field of environmental protection, and the sources and scale of its pollution from the process of energy production in a conventional way also lead to social pressure on public authorities. As a result of this pressure, among other things, some public institutions are dynamizing activities increasing the share of energy produced from renewable sources in the national energy demand. At the national level, it is crucial to ensure energy security, understood as the ability to deliver a sufficient amount of energy at a price that consumers can pay while respecting the rules of environmental protection $[26,49,50]$. Recently, the concept of energy security has also been emphasized in dimensions such as sustainability and energy efficiency [51]. In this context, an important yet ambiguous role of RES is also observed [52].

The production of energy from renewable sources is more decentralized than in the case of conventional ones, where frequently the production sites are located in the vicinity of energy sources extraction sites (e.g., lignite mines). The dispersion of renewable energy production sites, which indicates a decentralization of the whole system, is conducive to increasing the role of local government units, particularly municipalities, within the said system.

In Poland, the basic territorial self-government units, i.e., municipalities, may constitute an entrepreneurial entity provided that they conduct a communal economy in the public utility sphere. The municipalities' own tasks in the field of, among others, water supply system and provision, sewage system, disposal and treatment of municipal sewage, and electricity, heat and gas supply, may be conducted by the local, self-government budget companies [53]. Therefore, it can be concluded that municipalities may be active in the field of renewable energy production. However, it does not exhaust the whole range of possibilities for municipal activities in the scope of RES development. They may also conduct informative and promoting activities on their territories, to advocate the use of RES by residents and business entities.

Rural areas, which account for more than $90 \%$ of Poland's territory [2], exhibit great potential for RES development [54-56]. They may become a significant supplier of renewable energy, obtained from solar, wind, water and biomass processing [57]. The RES sector development offers a great opportunity for agricultural diversification and multifunctional rural development as well $[58,59]$. Another significant problem consists of the outdated national electricity grid. As a result, there are considerable difficulties with connecting power generators to the main power supply point, and the distribution of electricity. For this reason, the emergence of dispersed and small energy producers (the development of prosumer energy) constitutes one of the most appropriate solutions for the RES sector development in rural areas of Poland [7].

In Poland, there are two main areas for the implementation of investments in RES by the local self-government units. The first one is the south-eastern part of the country, specifically Małopolskie and Lubelskie voivodeships, where over $25 \%$ of the investments are located (and the use of solar energy prevails). The second area is western and central Poland (Łódzkie, Wielkopolskie and Pomorskie voivodeships), where $30 \%$ of all RES projects were implemented, primarily wind power plants [60].

Rural areas are currently becoming an important part of the debate on the longterm development of renewable energy. This indicates a new, intelligent specialization of rural areas as a provider of green energy, whose actions thus positively contribute to the prevention of climate change [61]. Since renewable energy sources constitute a part of the European Union's energy and climate policy, they are supported by structural 
funds. In the previous programming period (2007-2013), EU funds allowed for acquiring funding for numerous investments in RES. The total value of projects cofinanced from these funds amounted to 2 billion euro [62]. In Poland, local self-government units are included in the primary beneficiaries of EU cohesion policy, also in terms of investments in RES (cf. [63-65]).

\section{Materials and Methods}

Member States are obliged to spend EU funds transparently, which involves publishing the appropriate data. In Poland, this responsibility applies to the Ministry of Investment and Economic Development [66]. From the base of nearly 75 thousand projects implemented within the 2014-2020 EU Perspective, those fulfilling the 04 objective of supporting the transition to a low-carbon economy in all sectors were identified for the study purposes. Projects involving RES in the field of electricity, wind, solar, biomass and other types of energy were subsequently identified. Three of the most expensive projects were excluded in order to eliminate the impact of outliers on the results of empirical research. Ultimately, the study covered 1117 projects, whose beneficiaries were rural and urban-rural municipalities. Therefore, 1548 rural and 628 urban-rural municipalities (as of 31 December 2018) constituted the subject of the research. The remaining empirical data on the investment activity and the socioeconomic position of the examined territorial units were obtained from the Local Data Bank of Central Statistical Office of Poland [2]. The results are presented in Polish currency (the key data were converted to euro as per the weighted average exchange rate of the National Bank of Poland [67].

Research on the evaluation of the investment activity of territorial units in RES in rural areas of Poland between 2014 and 2020 consisted of three stages. The first one presents the theoretical basis for the implementation of RES investments in Poland and subsequently evaluated the investment activity of municipalities in acquiring EU subsidies in the area of environmentally friendly energy. Then, the results of the modeling of socioeconomic, financial and environmental conditions of the investment activity in RES in rural areas, cofinanced from EU funds, were presented.

To test the significance of differences between the average values of implemented RES projects, an analysis of variance was applied. Due to the lack of normality in the distribution of the analyzed variables in the distinguished groups, a non-parametric ANOVA analysis of Kruskal-Wallis rank was performed. Moreover, selected methods of descriptive statistics were used as well. Tabular and graphical methods of data presentation were applied.

The process of acquiring EU projects related to renewable energy sources by local selfgovernment units is conditioned by many factors, including the socioeconomic, financial and environmental ones. The empirical research was also aimed at determining the relations between the probability of occurrence of EU projects related to RES in a given territorial unit and a group of independent variables constituting the socioeconomic, financial and environmental conditions, presented in Table 1 . The explanatory variables were selected based on substantive grounds (i.e., the authors' knowledge of and several years of experience in that domain, and other authors' research). Statistical features were also taken into consideration. Strongly intercorrelated variables were removed from the set of explanatory variables. To do that, an analysis was carried out of correlation coefficients between the explanatory variables covered by this study.

When a dependent variable is a categorical variable assuming two values (usually the occurrence and absence of a phenomenon), suitable methods of modeling the analyzed phenomenon for a dichotomous variable should be applied (e.g., logistic regression or discriminative model). Logistic regression was used for this purpose. This method is applied when the dependent variable is dichotomous-assumes two values- 0 and 1 , where: value 1 indicates the possession of a given attribute while 0 - the lack thereof [68]. The usefulness of such a method may be attributed to the fact that the explanatory variables (i.e., predictors) can be measured on a metric and non-metric scale. The most important advantage of modeling data using this method is that the result is a single mathematical 
formula. It allows determining to what extent and in which direction individual variables influence the modeled phenomenon.

The logistic function, which the logistic regression model is based on, assumes the following form [69]:

$$
f(z)=\frac{e^{z}}{1+e^{z}}
$$

It adopts values from 0 to 1 . The value of the logistic function approaches 0 when $z$ aims at minus infinity. However, when $z$ aims at plus infinity, the logistic function approaches 1 . The surveyed rural and urban-rural municipalities in Poland were divided into two separate classes:

$$
y_{i}=\left\{\begin{array}{l}
0 \text { territorial units that did not implement EU projects related to RES } \\
1 \text { territorial units that implemented EU projects related to RES }
\end{array}\right.
$$

The logit regression method is most frequently used to determine the probability of occurrence of a certain $Y$ event, provided that the events $X_{1}, X_{2}, \ldots, X_{K}$ transpire as well. This method is applied, among others, in modeling the probability of the examined unit being in a certain state $(Y=1)$, and enables the identification of statistically significant factors influencing this probability. Such probability is determined by the following logit regression model [70]:

$$
P\left(y_{i}=1 / X\right)=\frac{e^{\beta_{0}+\beta_{1} x_{1}+\ldots+\beta_{K} x_{K}}}{1+e^{\beta_{0}+\beta_{1} x_{1}+\ldots+\beta_{K} x_{K}}},
$$

where:

$y_{i}-i$ th $(i=1, \ldots, n)$ observation on a dichotomous explanatory variable that assumes a value of 1 or 0 ;

$k=1,2, \ldots, K$;

$X_{i 1}, \ldots, X_{i K}$-explanatory variables (socio-economic, financial and environmental characteristics);

$P\left(y_{i}=1 / X\right)$ - the probability that the variable $Y$ would assume a value equal to 1 for the values of the explanatory variables $X=\left[X_{i k}, \ldots, X_{i K}\right], i=1, \ldots, n ; k=1, \ldots, K$;

$\beta_{0}, \beta_{1}, \ldots, \beta_{K}$-structural parameters of the model.

The parameters of the $\beta_{0}, \beta_{1}, \ldots, \beta_{K}$ model are most frequently determined by the highest reliability method, maximizing the logarithm of the reliability function in relation to the model parameters through iterative mathematical procedures. In the logit regression models, the structural parameters of the $\beta_{k}$ model are not directly interpretable, similarly to the linear model. They should not be interpreted in terms of changes in the value of $X_{k}$, only in terms of the direction of the relationship between $X_{k}$ and $Y$. The symbol of the parameter $X_{k}$ defines the direction of the influence of $X_{k}$ on $Y$. With a positive $\beta_{k}$, along with the increase of $X_{k}$ rises the probability that $Y=1$, while negative values of $\beta_{k}$ are associated with a decrease in the probability that $Y=1$. Possibilities of interpretation are provided by the transformation of the estimated equation into the so-called quotient of probability [71]:

$$
\Psi=\frac{P_{i}}{1-P_{i}}
$$

The quotient determines the relative probability of occurrence of a given event. In the logit regression model, which shapes the probability values, it is possible to estimate the level of probability as a function of independent variables. This quotient is simplified to the form of:

$$
\psi=e^{\beta_{o}+\beta_{1} x_{1}+\ldots+\beta_{K} X_{K}} .
$$

Expression $e^{\beta_{k}}$ constitutes a relative change in the probability of an event occurring as a result of a factor described by $X_{k}$, assuming the stability of the remaining variables included 
in the model. This value is interpreted by comparing it with value 1 and expressing the difference as a percentage. If [72]:

- $e^{\beta_{k}}>1$, then the factor described by $X_{k}$ variable is considered to stimulate the probability of occurrence of a given phenomenon, with a stable influence of the other variables included in the model,

- $e^{\beta_{k}}<1$, then the factor described by the $X_{k}$ variable is considered to reduce the probability of occurrence of a given phenomenon, with a stable influence of the other variables included in the model,

- $e^{\beta_{k}}=1$, then the factor described by $X_{k}$ variable is considered to have no effect on the probability of occurrence of a given phenomenon, with a stable influence of the other variables included in the model.

The evaluation of the logit model accuracy is conducted by means of chi-squared statistics and the so-called pseudo- $R^{2}$ measures [73]. The value of chi-squared statistics verifies the hypothesis that the explanatory variables introduced into the model do not introduce any significant information beyond that provided by the constant term. Verification of the statistical significance of variables is conducted based on the Wald test. In addition to the accuracy, the model predictive ability is also evaluated using the measure of predictive ability of a model determined based on the accuracy table - the so-called count (overall model accuracy) [74].

Table 1. Definition of explanatory variables adopted in the logit regression models.

\begin{tabular}{|c|c|}
\hline Variable Designation & Variable Name \\
\hline \multicolumn{2}{|r|}{ Socioeconomic Conditions } \\
\hline$x_{11}$ & Population density (persons per $\mathrm{km}^{2}$ ) \\
\hline$x_{12}$ & Old-age dependency ratio \\
\hline$x_{13}$ & Natural increase per 10 thousand population \\
\hline$x_{14}$ & Percentage of councillors with higher education (\%) \\
\hline$x_{15}$ & Cumulative net migration rate per 1000 persons from 2016-2018 \\
\hline$x_{16}$ & Entities entered into the REGON (National Business Register) per 10 thousand population \\
\hline$x_{17}$ & Entities of the national economy employing more than 49 people per 10 thousand inhabitants \\
\hline$x_{18}$ & Natural persons conducting business activity per 10 thousand inhabitants \\
\hline$x_{19}$ & Foundations, associations and social organisations per 10 thousand inhabitants \\
\hline$x_{10}$ & Percentage of persons using the water supply system $(\%)$ \\
\hline$x_{11}$ & Percentage of persons using the sewage system $(\%)$ \\
\hline$x_{12}$ & Percentage of people using the gas network $(\%)$ \\
\hline$x_{13}$ & Number of dwellings per 1000 inhabitants \\
\hline$x_{14}$ & Average floor space per capita (in $\mathrm{m}^{2}$ ) \\
\hline$x_{15}$ & Beneficiaries of social care per 10 thousand population \\
\hline$x_{16}$ & Unemployment rate $(\%)$ \\
\hline$x_{17}$ & Accommodations per 10 thousand inhabitants \\
\hline$x_{18}$ & Share of the agricultural holdings of 15 ha and more $(\%)$ \\
\hline$x_{19}$ & Number of persons employed in individual agricultural holdings per 100 population of working age \\
\hline \multicolumn{2}{|r|}{ Financial Conditions } \\
\hline$x_{20}$ & Total income per capita in PLN \\
\hline$x_{21}$ & Level of personal income per capita in PLN \\
\hline$x_{22}$ & Shares in taxes constituting the state budget revenue (PIT and CIT) per capita in PLN \\
\hline$x_{23}$ & General subsidy level excluding the educational part per capita in PLN \\
\hline$x_{24}$ & Current transfers per capita in PLN \\
\hline$x_{25}$ & Share of the current income in total income $(\%)$ \\
\hline$x_{26}$ & Share of the personal income in total income (\%) \\
\hline$x_{27}$ & Level of property expenditures per capita in PLN \\
\hline$x_{28}$ & European Union funds for financing EU programmes and projects in 2014-2019 per capita in PLN \\
\hline$x_{29}$ & Share of the operating surplus in total income $(\%)$ \\
\hline$x_{30}$ & Share of property expenditures in total expenditures $(\%)$ \\
\hline$x_{31}$ & Burdening current expenditures with remuneration and related expenses \\
\hline
\end{tabular}


Table 1. Cont.

\begin{tabular}{cc}
\hline Variable Designation & Variable Name \\
\hline & Financial Conditions \\
\hline$x_{32}$ & Share of the operating surplus and income from the sale of assets \\
$x_{33}$ & Operating surplus per capita in PLN \\
$x_{34}$ & Total liabilities per capita in PLN \\
$x_{35}$ & Share of total liabilities in total income (\%) \\
$x_{36}$ & Burdening total income with debt service expenditures (\%) \\
$x_{37}$ & Burdening personal income with debt service expenditures $(\%)$ \\
$x_{38}$ & Share of due liabilities in total liabilities \\
\hline & Environmental Conditions \\
\hline$x_{39}$ & Afforestation (\%) \\
$x_{40}$ & Underwater land (\%) \\
$x_{41}$ & Protected area in total surface area (\%) \\
$x_{42}$ & Agricultural land (\%) \\
$x_{44}$ & Built-up and urbanised areas (\%) \\
$x_{45}$ & Ecological land (\%) \\
$x_{46}$ & Wastelands (\%) \\
$x_{47}$ & Share of the industry in water consumption (\%) \\
& Water consumption per capita (in $\left.\mathrm{m}^{3}\right)$ \\
\hline
\end{tabular}

Source: Own study based on [75-79].

\section{Results of Empirical Studies}

\subsection{Local Investments in Environmentally Friendly Energy, Cofinanced by the European Union in Poland}

Objectives of the EU's cohesion policy indicate support for investment in energy infrastructure while the adopted system of thematic targets of the said policy includes the term "low-carbon economy", referring to the reduction of carbon emissions. Poland belongs to the group of EU countries where the share of energy obtained from renewable sources constitutes less than 15\% while the average for the Member States amounted to as high as 30\% in 2018 [80]. In 2018, EU leaders determined an objective, according to which, by $2030,32 \%$ of the energy consumption within the Union is to be derived from renewable sources [81]. Achieving such a formulated strategic target requires the involvement of significant funds to finance investments in this area. The primary sources of funding for energy projects are EU funds, both from the general budget and the structural funds.

Poland has favorable geographical and environmental conditions for the production of energy from renewable sources, particularly considering the potential for the production of environmentally friendly energy through agriculture (cultivation of energy crops and production of energy from biogas) and rural areas [24,82]. The largest resources of renewable energy sources occur in rural areas, yet the same areas simultaneously have the greatest problems with ensuring continuity and quality of the supplied energy [83]. Power cuts hinder agricultural activity and restrict opportunities for the development of entrepreneurship in rural areas. Difficulties in ensuring a stable energy supply of satisfactory quality result from several reasons, particularly outdated or underdeveloped infrastructure of energy distribution. Energy balancing may be supported by local renewable energy sources. Both the RES potential of rural areas and the dispersion of buildings speak in favor of such a solution. The employment of locally available energy sources, particularly those directly related to agricultural production, may improve local energy security and facilitate farmers' fulfillment of environmental protection requirements [9]. In rural areas, the support of RES development through EU funds is consistent with the concept of multifunctional development of agriculture, rural areas and, as Klepacka [22] notes, the idea of sustainable development. It constitutes a certain alternative to the dominant role of agricultural activity - the production of food raw materials. The second pillar of the Common Agricultural Policy, which funds the Rural Development Program for 2014-2020 [9], 
stipulates multiannual support for rural development aimed at increasing competitiveness of farms, and sustainable development of the natural resources management, including the use of energy from renewable sources.

The empirical studies aimed at assessing the scale and importance of local investments in the field of RES in rural areas of Poland, cofinanced from the EU funds. To do that, the energy projects, cofinanced by the EU budget and implemented by the basic, territorial, self-government units, i.e., municipalities in 2014-2020 were characterized. The attention was focused primarily on projects implemented by rural and urban-rural municipalities. The research revealed that 2777 projects in the field of energy have been conducted within the 2014-2020 Perspective, amounting to PLN 12.99 billion (EUR 2.92 billion), of which nearly $75.8 \%$ has been financed from the EU budget. Local self-governments constitute their most active beneficiaries. They have been implementing 1153 projects (i.e., almost $42 \%$ of all energy-related projects), amounting to PLN 4.32 billion (EUR 0.97 billion). Private entities are party to a much higher number of implemented projects. However, they are characterized by a significantly higher capital intensity [66].

Within the local self-government sector, the most active local investments in the field of RES are realized by its basic entities, i.e., municipalities. Projects implemented by municipalities constitute as much as $95.1 \%$ of the total number and over $97 \%$ of the total value of projects realized by the local self-government sector. Therefore, municipalities are the most active group of beneficiaries. In the examined period, an average municipality implemented activities in the field of RES whose value amounted to PLN 3.67 million (EUR 0.83 million). Considering their administrative type, the diversity of implemented projects in terms of an average level is high, which was confirmed by the Kruskal-Wallis test $(K W=4.97$ with $p=0.002)$. On average, the largest activities of this type were undertaken by cities, smaller by urban-rural self-governments, while the smallest occurred in cities with poviat rights and rural municipalities. Analyzing the percentage of entities benefiting from this form of support, the highest was a characteristic of cities with poviat rightsnearly every second city used such support. In the case of other types of municipalities, the percentage of those that acquire EU funds is significantly lower. In total, rural and urbanrural municipalities are characterized by the highest number of implemented projects- $67 \%$ and $20 \%$ respectively. The projects accounted respectively for $60 \%$ and $23 \%$ of the total value of undertaken activities in the field of RES (Table 2).

Table 2. Characteristics of the renewable energy source (RES) projects, cofinanced by the European Union and implemented under the 2014-2020 Financial Perspective by municipalities in Poland.

\begin{tabular}{cccccc}
\hline $\begin{array}{c}\text { Type of } \\
\text { Municipality }\end{array}$ & $\begin{array}{c}\text { Number of } \\
\text { Projects }\end{array}$ & $\begin{array}{c}\text { Average Value of } \\
\text { Projects (PLN } \\
\text { Million) }\end{array}$ & $\begin{array}{c}\text { Total Value of } \\
\text { Projects (PLN } \\
\text { Million) }\end{array}$ & $\begin{array}{c}\text { Number of Municipalities } \\
\text { Acquiring Resources from } \\
\text { the EU Funds }\end{array}$ & $\begin{array}{c}\text { Percentage of Municipalities } \\
\text { Acquiring Resources from the } \\
\text { EU Funds (\%) }\end{array}$ \\
\hline $\begin{array}{c}\text { urban-rural } \\
\text { rural }\end{array}$ & 224 & 4.14 & 928 & 168 & 26.75 \\
$\quad \begin{array}{c}\text { urban } \\
\text { cities with poviat }\end{array}$ & 945 & 3.32 & 2476 & 539 & 34.82 \\
$\begin{array}{c}\text { rights } \\
\text { Total }\end{array}$ & 59 & 5.44 & 500 & 69 & 29.24 \\
\hline
\end{tabular}

Source: Own study based on [66].

Interestingly, it is possible to distinguish a significant group of municipalities whose success in acquiring the first EU subsidy in the field of energy has translated into further successes. The leaders in acquiring subsidies are primarily rural and urban-rural municipalities: Stanin, Ryki, Rajgród, Psary, Inowłódź, Drohiczyn and Daszyna (each of them is implementing four projects). In total, as many as 210 local self-governments $(26 \%)$ implemented more than one project in the field of RES. The support obtained consists of a non-refundable grant. Half of the projects have been completed, the remaining ones are to be finished in 2021 at the latest. 
All projects are implemented by municipalities within the Regional Operational Programs, i.e., programs dedicated to the needs of beneficiaries from a particular region. In the case of support obtained by the surveyed municipalities, their spatial diversity may be observed. In this respect, statistically significant differences were confirmed by the Kruskal-Wallis test $(K W=11.04$ with $p=0.000)$. Considering the level of investments in the field of RES, by far, the highest amount of funds was spent by the municipalities from Lubelskie, Podkarpackie and Ślaskie voivodeships, which in total constituted more than a half of all projects. There is also a significant yet smaller concentration of the implemented projects in RES. In this case, Lubelskie, Podlaskie and Ślaskie voivodeships were the leading municipalities. The aforementioned results have translated into a large variation in values of an average project (Table 3).

Table 3. Characteristics of the RES projects, cofinanced by the European Union and implemented by urban-rural and rural municipalities under the 2014-2020 Financial Perspective in Poland, divided into Regional Operational Programs (ROP).

\begin{tabular}{|c|c|c|c|c|c|c|c|c|c|}
\hline \multirow[b]{2}{*}{ Programmes } & \multicolumn{3}{|c|}{ Total Municipalities } & \multicolumn{3}{|c|}{ Urban-Rural Municipalities } & \multicolumn{3}{|c|}{ Rural Municipalities } \\
\hline & $\begin{array}{c}\text { AVP * } \\
\text { (PLN } \\
\text { Million) }\end{array}$ & $\begin{array}{c}\text { VP ** } \\
\text { (PLN } \\
\text { Million) }\end{array}$ & $\mathbf{N P} * * *$ & $\begin{array}{c}\text { AVP * } \\
\text { (PLN } \\
\text { Million) }\end{array}$ & $\begin{array}{c}\text { VP ** } \\
\text { (PLN } \\
\text { Million) }\end{array}$ & $\mathbf{N P} * * *$ & $\begin{array}{c}\text { AVP * } \\
\text { (PLN } \\
\text { Million) }\end{array}$ & $\begin{array}{c}\text { VP ** } \\
\text { (PLN } \\
\text { Million) }\end{array}$ & $\mathbf{N P} * * *$ \\
\hline Dolnośląskie ROP & 3.36 & 30.22 & 9 & 4.21 & 25.24 & 6 & 2.10 & 4.21 & 2 \\
\hline $\begin{array}{c}\text { Kujawsko-Pomorskie } \\
\text { ROP }\end{array}$ & 1.07 & 76.19 & 71 & 1.21 & 12.09 & 10 & 1.10 & 54.89 & 50 \\
\hline Lubelskie ROP & 3.82 & 1079.77 & 283 & 4.47 & 165.34 & 37 & 3.66 & 830.55 & 227 \\
\hline Lubuskie ROP & 0.44 & 0.88 & 2 & 0.50 & 0.50 & 1 & 0.38 & 0.38 & 1 \\
\hline Łódzkie ROP & 3.51 & 417.71 & 119 & 6.79 & 115.46 & 17 & 2.85 & 262.19 & 92 \\
\hline Małopolskie ROP & 3.28 & 374.01 & 114 & 1.97 & 72.81 & 37 & 3.34 & 220.48 & 66 \\
\hline Mazowieckie ROP & 8.82 & 273.36 & 31 & 7.71 & 46.25 & 6 & 8.97 & 215.25 & 24 \\
\hline Opolskie ROP & 9.59 & 38.34 & 4 & 12.10 & 36.30 & 3 & 0.00 & 0.00 & 0 \\
\hline Podkarpackie ROP & 7.32 & 629.56 & 86 & 7.38 & 169.83 & 23 & 7.07 & 360.34 & 51 \\
\hline Podlaskie ROP & 1.45 & 205.46 & 142 & 1.34 & 55.11 & 41 & 1.01 & 82.53 & 82 \\
\hline Pomorskie ROP & 7.19 & 122.25 & 17 & 6.83 & 13.65 & 2 & 7.74 & 100.66 & 13 \\
\hline Śląskie ROP & 3.61 & 508.38 & 141 & 7.96 & 95.46 & 12 & 1.97 & 149.63 & 76 \\
\hline Świętokrzyskie ROP & 4.61 & 124.48 & 27 & 4.90 & 53.89 & 11 & 4.41 & 66.22 & 15 \\
\hline $\begin{array}{c}\text { Warmińsko-Mazurskie } \\
\text { ROP }\end{array}$ & 0.71 & 26.82 & 38 & 1.10 & 7.71 & 7 & 0.62 & 16.01 & 26 \\
\hline Wielkopolskie ROP & 7.34 & 168.76 & 23 & 7.74 & 54.18 & 7 & 7.25 & 94.29 & 13 \\
\hline $\begin{array}{c}\text { Zachodniopomorskie } \\
\text { ROP }\end{array}$ & 1.86 & 18.57 & 10 & 1.07 & 4.26 & 4 & 1.13 & 4.52 & 4 \\
\hline Total & 3.67 & 4094.77 & 1117 & 4.14 & 928.08 & 224 & 3.32 & 2462.17 & 742 \\
\hline
\end{tabular}

* AVP—the average value of projects, ${ }^{* *} \mathrm{VP}$ - the value of projects, ${ }^{* * *} \mathrm{NP}$-the number of projects. Source: Own study based on [66].

The concentration of RES investment activity in the area of several voivodeships occurred also in the case of projects implemented by urban-rural and rural municipalities. Particularly great interest in this type of project has been observed in municipalities of Eastern Poland, especially Lubelskie Voivodeship, whose local self-governments lead both in terms of value and number of implemented projects. Such a result was influenced by the exceptional investment activity of rural municipalities. Surprising may be the fact that, in the Opolskie Voivodeship, only three municipalities decided to conduct the surveyed investments in their areas. Additionally, low interest in such undertakings was observed in Zachodniopomorskie and Pomorskie voivodeships, which are predisposed to implement wind energy (Figure 1). 

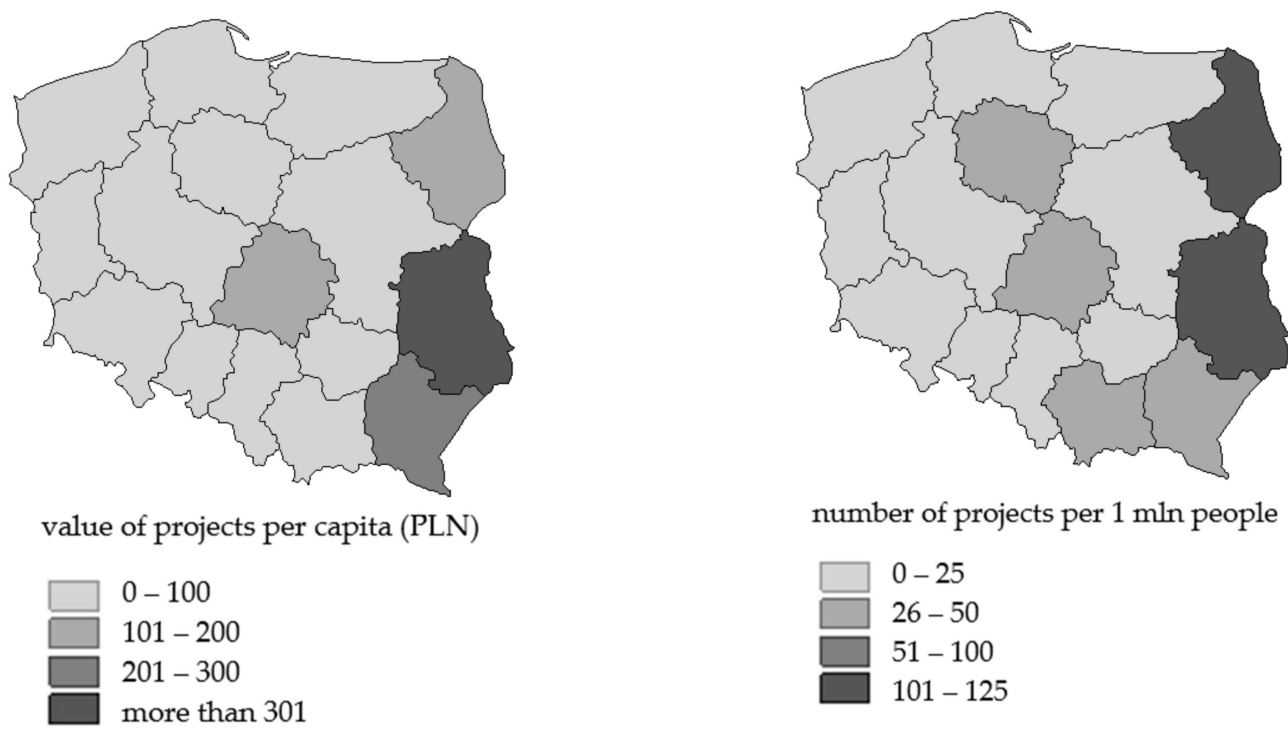

number of projects per $1 \mathrm{mln}$ people

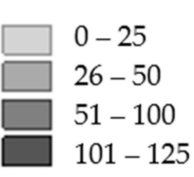

Figure 1. Projects in RES, implemented by urban-rural and rural municipalities, cofinanced by the EU under the 2014-2020 Financial Perspective in Poland by regions. Source: Own study based on [66].

The majority of Polish municipalities acquired subsidies within the 010 Renewable Energy: solar area ( 879 projects, i.e., $78 \%$ of their total number), absorbing more than PLN 3.40 billion (EUR 0.77 billion), which constitutes $83 \%$ of their total amount (Table 4 ). It is worth noting that activities in the scope of solar energy were the most capital-intensive. The second area of interest for Polish municipalities is the 083 Air Quality Measures. According to the design nomenclature, more than half of these projects involved 22 activities concerning the environment and climate change (projects involved: reducing low-stack emission by promoting and funding the replacement of residential wood heaters with new heating devices using gas or biomass), every third one involved 18 Public Administration (including, among others, public utility buildings thermal efficiency improvement), and the remaining ones involved 10 grid energy, gas fuels, steam, hot water and air for air conditioning systems (included the replacement of heat sources with those indicated in the title). Within the remaining areas, only around a few to a dozen projects were implemented. Such a structure of implemented RES projects was characteristic for urban-rural and rural municipalities, while rural self-governments also implemented individual projects within the remaining support areas, i.e., hydroelectric, geothermal, marine, biomass, wind or electrical energy. The Kruskal-Wallis test $(2.97$ with $p=0.002)$ confirmed the statistically significant allocation of funds within the areas of the supporting transition towards a low $\mathrm{CO}_{2}$ emissions economy (Table 4).

Implementation of the said projects was aimed at reducing the negative impact on the environment and decreasing the energy consumption. Municipalities received subsidies primarily for measures improving the energy efficiency of facilities from the public and residential sectors, frequently by increasing the efficiency of existing installations and equipment. These projects involved the reconstruction of heating installations, ventilation and air-conditioning systems, insulation of facilities, replacement of windows, external doors and low-efficiency boilers, change of water and sewage systems and lighting systems into energy-efficient ones, installation of RES in electrically modernized facilities, installation of cooling systems, including those from RES, and installation or reconstruction of electric energy and heat-generating units in high-efficiency combined heat and power (CHP). The subsidy could be granted for an economically justified construction with the lowest possible emission of $\mathrm{CO}_{2}$ and other air pollutants. In turn, any reconstruction of the existing installations to high-efficiency $\mathrm{CHP}$ was bound to result in a reduction of at least $30 \%$ of $\mathrm{CO}_{2}$ emission (the 2014-2020 WROP was used as an example [84]). 
Table 4. Characteristics of the RES projects, cofinanced by the European Union and implemented by urban-rural and rural municipalities under the 2014-2020 Financial Perspective, divided into areas of support.

\begin{tabular}{|c|c|c|c|c|c|c|c|c|c|}
\hline \multirow[b]{2}{*}{ Area of Project Intervention } & \multicolumn{3}{|c|}{ Total Municipalities } & \multicolumn{3}{|c|}{ Urban-Rural Municipalities } & \multicolumn{3}{|c|}{ Rural Municipalities } \\
\hline & $\begin{array}{c}\text { AVP * } \\
\text { (PLN } \\
\text { Million) }\end{array}$ & $\begin{array}{c}\text { VP ** } \\
\text { (PLN } \\
\text { Million) }\end{array}$ & $\mathbf{N P} * * *$ & $\begin{array}{c}\text { AVP * } \\
\text { (PLN } \\
\text { Million) }\end{array}$ & $\begin{array}{c}\text { VP ** } \\
\text { (PLN } \\
\text { Million) }\end{array}$ & $\mathbf{N P} * * *$ & $\begin{array}{c}\text { AVP * } \\
\text { (PLN } \\
\text { Million) }\end{array}$ & $\begin{array}{c}\text { VP ** } \\
\text { (PLN } \\
\text { Million) }\end{array}$ & $\mathbf{N P} * * *$ \\
\hline $\begin{array}{l}005 \text { Electricity (storage and } \\
\text { transmission) }\end{array}$ & 1.63 & 1.63 & 2 & 0.00 & 0.00 & 0 & 0.00 & 0.00 & 0 \\
\hline 010 Renewable Energy: Solar & 3.89 & 3422.63 & 879 & 4.45 & 708.22 & 159 & 3.57 & 2175.31 & 610 \\
\hline 011 Renewable Energy: from Biomass & 1.88 & 20.71 & 11 & 4.22 & 8.43 & 2 & 1.36 & 12.28 & 9 \\
\hline 012 Other Renewable Energy ${ }^{(a)}$ & 2.09 & 43.93 & 21 & 2.14 & 6.42 & 3 & 2.60 & 28.65 & 11 \\
\hline 083 Air Quality Measures & 2.97 & 605.87 & 204 & 3.42 & 205.01 & 60 & 2.20 & 245.93 & 112 \\
\hline Total & 3.67 & 4094.77 & 1117 & 4.14 & 928.08 & 224 & 3.32 & 2462.17 & 742 \\
\hline
\end{tabular}

${ }^{*}$ AVP—the average value of projects, ${ }^{* *} \mathrm{VP}$ - the value of projects, ${ }^{* * *} \mathrm{NP}$-the number of projects. ${ }^{(a)}$ Including hydroelectric, geothermal and marine) and integration of renewable energy (including storage, conversion of electricity to gas and infrastructure). Source: Own study based on [66].

4.2. The Shaping of Investment Activity of Rural and Urban-Rural Municipalities in the Field of Environmentally Friendly Energy Projects Cofinanced by the European Union

In rural areas, the investment activity of territorial units in environmentally friendly energy is highly diversified regionally, as shown in Figure 1. In order to identify the main determinants of investment activity of rural and urban-rural municipalities in RES, a logit model was applied. It was used to determine the direction and strength of influence of individual factors on the activity of territorial units in acquiring projects in the area of environmentally friendly energy, cofinanced from the EU budget. This method is applied, among others, in modeling the probability of the examined unit being in a certain state $(Y=1)$, and enables the identification of statistically significant factors influencing this probability. Logit regression models are used in the case of the dichotomous explained variable ( 0 - the municipality did not acquire any project, 1 -the municipality acquired at least one project in the area of RES, cofinanced by the EU funds under the 2014-2020 Financial Perspective). Three logit models were estimated, demonstrating respectively the influence of socioeconomic, financial and environmental factors on the investment activity of the surveyed territorial units in acquiring projects cofinanced by the EU in the field of environmentally friendly energy. The assessment of the constructed models was conducted based on the analysis of classification tables (assessment of predictive ability), chi-squared statistics (assessment of model significance) and the Wald test (determination of the significance of explanatory variables). The results of the estimated logit models were presented in Table 5. The estimated models were characterized by high accuracy with respect to the empirical data, and high statistical significance $(p<0.05)$ of parameters occurring with explanatory variables.

The empirical studies revealed that, among the socioeconomic factors, the municipal investment activity in acquiring RES projects cofinanced from EU funds is significantly influenced by the demographic situation, level of entrepreneurship development, number of persons employed on agricultural holdings per 100 population of working age and the social situation. Empirical studies proved that the rising value of explanatory variables, such as population density and net migration rate per 1000 persons, has increased the probability of municipalities acquiring a project cofinanced by the EU in the field of RES. High demographic potential is associated with higher income tax revenues of basic territorial units, which translates into higher potential and investment capacity (Table 5). 
Table 5. Results of the estimated logit models parameters of investment activity in RES of rural and urban-rural municipalities in Poland in 2014-2020 (a).

\begin{tabular}{|c|c|c|c|c|c|c|}
\hline \multicolumn{2}{|c|}{ Explanatory (Independent) Variables } & Coefficient & $\begin{array}{l}\text { Standard } \\
\text { Error }\end{array}$ & $\begin{array}{l}\text { Probability } \\
\text { Ratio }\end{array}$ & $p$-Values & Relevance $^{(b)}$ \\
\hline \multirow{8}{*}{ Socio-economic ${ }^{(c)}$} & const & 0.3130 & 0.4651 & 1.3676 & 0.5009 & \\
\hline & Population density (persons per $\mathrm{km}^{2}$ ) & 0.0053 & 0.0010 & 1.0053 & $<0.0001$ & $* * *$ \\
\hline & $\begin{array}{l}\text { Cumulative net migration rate per } 1000 \\
\text { persons from 2016-2018 }\end{array}$ & 0.0173 & 0.0041 & 1.0174 & $<0.0001$ & $* * *$ \\
\hline & $\begin{array}{l}\text { Entities entered into the REGON } \\
\text { (National Business Register) per } 10 \\
\text { thousand population }\end{array}$ & -0.0022 & 0.0004 & 0.9978 & $<0.0001$ & $* * *$ \\
\hline & $\begin{array}{l}\text { Share of the agricultural holdings of } 15 \\
\text { ha and more (\%) }\end{array}$ & -0.0228 & 0.0053 & 0.9774 & $<0.0001$ & $* * *$ \\
\hline & $\begin{array}{l}\text { Number of persons employed in } \\
\text { individual agricultural holdings per } \\
100 \text { population of working age }\end{array}$ & 0.0177 & 0.0042 & 1.0179 & $<0.0001$ & $* * *$ \\
\hline & $\begin{array}{l}\text { Beneficiaries of social community care } \\
\text { per } 10 \text { thousand population }\end{array}$ & 0.0006 & 0.0002 & 1.0006 & 0.0009 & $* * *$ \\
\hline & $\begin{array}{l}\text { Percentage of councillors with higher } \\
\text { education }(\%)\end{array}$ & 0.0067 & 0.0041 & 1.0067 & 0.0986 & * \\
\hline \multirow{4}{*}{ Financial $^{(d)}$} & const & 0.4104 & 0.1778 & 1.5074 & 0.021 & $* *$ \\
\hline & $\begin{array}{c}\text { Share of the personal income in total } \\
\text { income }(\%)\end{array}$ & -0.0237 & 0.0047 & 0.9766 & $<0.0001$ & $* * *$ \\
\hline & $\begin{array}{l}\text { European Union funds for financing } \\
\text { EU programmes and projects in } \\
\text { 2014-2019 per capita in PLN }\end{array}$ & 0.0006 & 0.0002 & 1.0006 & 0.011 & ** \\
\hline & $\begin{array}{l}\text { Level of property expenditures per } \\
\text { capita (in PLN) }\end{array}$ & 0.0003 & 0.0001 & 1.0003 & $<0.0001$ & $* * *$ \\
\hline \multirow{5}{*}{ Environmental (e) } & const & 0.3423 & 0.12307 & 1.4082 & 0.0054 & $* * *$ \\
\hline & Protected area in total surface area (\%) & -0.0030 & 0.0012 & 0.9970 & 0.0102 & ** \\
\hline & Underwater land (\%) & -0.0832 & 0.0252 & 0.9202 & 0.0010 & $* * *$ \\
\hline & Built-up and urbanised areas (\%) & -0.0355 & 0.0179 & 0.9651 & 0.0469 & ** \\
\hline & Wastelands (\%) & 0.0715 & 0.0401 & 1.0741 & 0.0749 & * \\
\hline
\end{tabular}

(a) The models were construed on the basis of balanced samples (approximately 700 municipalities), which acquired at least 1 project in RES, cofinanced by the EU (1) and over 700 municipalities, which did not exhibit any investment activity in this area (0). ${ }^{(b)}$ If $p$-value $<0.001$ it is given three stars $\left(^{* * *}\right), 0.001<p$-value $<0.05$-two stars $\left(^{* *}\right)$ and $0.05<p$-value $<0.1$-one star $\left({ }^{*}\right)$. ${ }^{(c)}$ Collective test of model coefficients: $\chi^{2}=180.7, p=0.000$ and number of cases of correct prediction $=64.1 \%$. ${ }^{(d)}$ Collective test of model coefficients: $\chi^{2}=48.1, p=0.000$ and number of cases of correct prediction $=60.2 \%$. (e) Collective test of model coefficients: $\chi^{2}=28.0, p=0.000$ and number of cases of correct prediction $=52.8 \%$. Source: Own calculations using the Gretl program, based on $[2,66,85]$.

Projects in the area of environmentally friendly energy, cofinanced by EU, are more frequently implemented by municipalities with a lower level of socioeconomic development, including territorial units characterized by a lower level of entrepreneurship development and typical agricultural functions. The results of the estimated logit model indicate that the higher the number of entities registered in the REGON (National Business Register) per 10 thousand population, the lower the probability of implementation of RES projects by the municipality. On the other hand, the higher the number of persons employed on agricultural holdings per 100 population of working age, the higher the probability of implementation of the discussed projects (Table 5).

Rural areas are facing serious problems such as depopulation and limited potential to develop non-agricultural economic functions. Moreover, the local self-governments focus their attention on the social benefits resulting from investments in RES, which are expressed primarily in the ability to create additional, stable jobs for less-skilled employees and economic activation of rural areas. Municipalities with a higher number of beneficiaries of environmental social assistance per 10 thousand population, and those with a high number of persons working on agricultural holdings per 100 population of working age, were characterized by an increased probability of acquiring a project in RES, cofinanced by the EU (Table 5).

The percentage of councilors with higher education was also a statistically significant variable, demonstrating the level of human capital in territorial self-government units. Many definitions reduce human capital to the issue of education. The human capital consists of all 
the predispositions, knowledge and skills, together with the competencies that allow them to be applied in specific actions [86]. The research determined that a rise in the percentage of councilors with a higher level of education increases the probability of a given territorial unit to acquire a project cofinanced from the EU in the area of RES (Table 5).

The study determined that, among the financial factors, the level of municipality's own income potential, investment activity and the activity in the field of acquiring EU funds are important for their investment activity in obtaining RES-related projects and projects cofinanced from the EU funds. As indicated earlier, projects in the area of environmentally friendly energy, which are cofinanced by the EU, are more frequently implemented by municipalities with a lower level of development and typically agricultural functions. The results of the estimated logit model for financial conditions determined that the higher the own income potential (quantified by the amount of own income per capita), the lower the probability of acquiring EU funds to cofinance the projects in RES. This confirms that entities interested in the implementation of such projects consist of agricultural municipalities, for which even limited financial independence [87] is not a significant barrier for applying for EU funds in RES. At the same time, the research revealed that municipalities with higher investment activity are more inclined to implement the discussed, projects cofinanced by the EU (Table 5). Such a result indicates a significant role of the beneficiary's experience in the process of applying for an EU subsidy. In a municipality, in which the employees have already conducted such projects and learned the procedures, the language of documentation and the method of completing application forms, it is easier to achieve success in the subsequent competition [88].

The research determined that among the last, i.e., the third group of environmental factors, the investment activity of municipalities in acquiring projects related to RES and cofinanced by the EU is significantly influenced by the percentage of protected areas, the underwater land, built-up and urbanized areas (\%) and wastelands (\%). However, among the aforementioned environmental factors, only a higher share of wastelands in the municipality's surface area translated into a higher probability of acquiring a project cofinanced by the EU related to RES. For instance, apart from roofs, photovoltaic panels may be installed on wastelands, by placing the installations required to produce electricity in their area. On the other hand, a higher share of the underwater land does not translate into a higher probability of acquiring the discussed projects by local self-governments (Table 5). Considering that Polish area, for the most part, consists of the lowlands (with no big natural slopes), it does not create favorable conditions for the construction of large hydroelectric power plants. In Poland, the majority of hydroelectric power plants are built on rivers.

\section{Political Implications}

All energy-related projects, cofinanced by the EU and implemented by the surveyed municipalities involved the 04 objective of supporting the transition to a low carbon economy in all sectors (Table 6). The said objective is consistent with the direction of the EU Climate Policy of reducing greenhouse gas emissions and targets of the EU Strategy for the Baltic Sea Region [89] in the field of climate change adaptation projects. Directions of the interventions undertaken within the framework of the 04 objective will enable approaching the achievement of the determined objectives of the Europe 2020 Strategy [90], involving primary energy consumption, the share of energy from renewable sources in the gross final energy consumption and the reduction of greenhouse gas emissions. Under the national law, the implementation of these activities is included in the Energy Policy of Poland until 2030 [91], the Energy Security and Environment Strategy [92], the Transport Development Strategy until 2020 (with a perspective until 2030) [93] and program documents in this area, primarily in the National Energy Efficiency Action Plan for Poland [94] and the National Renewable Energy Action Plan [95]. 
Table 6. Intervention priorities under the 04 objective of supporting the transition to a low-carbon economy in all sectors.

\begin{tabular}{|c|c|c|}
\hline $\begin{array}{l}\text { Increasing Energy Efficiency of } \\
\text { the Economy }\end{array}$ & $\begin{array}{l}\text { Reducing Emissions Generated by } \\
\text { Transport in Urban Agglomerations }\end{array}$ & $\begin{array}{l}\text { Increasing Energy Production from } \\
\text { Renewable Sources }\end{array}$ \\
\hline $\begin{array}{l}\text { increasing the energy efficiency of public } \\
\text { facilities and multifamily } \\
\text { residential buildings; } \\
\text { increasing energy efficiency in enterprises; } \\
\text { improving heating and cooling systems, as } \\
\text { well as supporting low-carbon strategies; } \\
\text { reducing the energy consumption by } \\
\text { constructing intelligent, medium and/or low } \\
\text { voltage distribution networks; } \\
\text { increasing energy production in highly } \\
\text { efficient installations (supporting highly } \\
\text { efficient CHP) }\end{array}$ & $\begin{array}{l}\text { developing low-emission public } \\
\text { transport and other environmentally } \\
\text { friendly forms of urban mobility }\end{array}$ & $\begin{array}{l}\text { increasing energy production from renewable sources } \\
\text { and the development of networks for RES; } \\
\text { increasing the efficiency of system operation by } \\
\text { constructing intelligent, medium and/or low voltage } \\
\text { distribution networks; } \\
\text { supporting the national industry providing the } \\
\text { equipment necessary for the production of energy from } \\
\text { renewable sources, as an industry with significant } \\
\text { development potential in the light of the increasing share } \\
\text { of RES in the energy mix. Supporting this type of projects } \\
\text { will also be consistent with the } 03 \text { thematic objective } \\
\text { (CT3), serving the development of enterprises. }\end{array}$ \\
\hline
\end{tabular}

Source: Own study based on [96].

As emphasized in the Partnership Agreement-Programming of the 2014-2020 Financial Perspective [90], considering the dependence of the Polish economy on coal as a primary energy source, the process of developing a low-carbon economy will be more timeconsuming and costly than in the case of many other EU countries. These measures aim not only at reducing primary energy consumption and $\mathrm{CO}_{2}$ emissions but also increasing the competitiveness of the economy.

In their new Multiannual Financial Framework for 2021-2027, the EU specified the priority projects to be cofinanced with structural funds. In 2021-2027, it is planned to allocate EUR 379 billion to goal 3 (natural resources and environment) and EUR 442 billion to goal 2 (cohesion and values). The plans provide for an allocation of EUR 114 billion more to climatic and environmental measures than in 2014-2020. Such an important change means giving priority to environmental issues, which, as a consequence, will translate into a greater use of renewable energies. The financial resources are supposed to support the implementation of the Green Deal. The environmental standards applicable in the EU are among the world's most stringent ones. Green growth is a key component in the EU policy designed to guarantee that Europe will follow an organic path of economic growth. The EU also plays a key role in promoting sustainable development at a global level [23].

The studies and findings derived from it could provide a basis for the creation of a new regional-level RES policy in Poland. Research findings confirm that considerable differences exist between the geographies in the implementation of RES investments cofinanced by the EU. Municipalities located in Eastern Poland proved to be the most efficient beneficiaries of that support despite being at lower levels of development and investment potential. So far, municipalities at higher development levels, located in territories affected by greater environmental pollution, have been passive in their quest for funds from the EU budget. They, too, should intensify the measures taken to develop RES in their territories. To do that, it is necessary to design a regionally diversified government policy for supporting RES investments implemented by LGUs.

\section{Discussion}

The interest in RES results, among other things, from the increase in energy demand, the ongoing climate change, the use of the surplus of agricultural raw materials and the maintenance of energy security in the EU [97]. Research carried out by, among others, Ossowska and the research team [98] indicates that in recent years, one might spot positive changes concerning the consumption of energy from renewable sources in the European Economic Community but these changes vary depending on a country. The type of renewable energy used depends on the geographical location and the economic and financial efficiency of each source. For example, Northern Europe has a more environmentally friendly energy policy. On the other hand, Fisher [99] and Ringel and Knodt [100] indicate that Central and Eastern Europe countries rely on their own energy. In countries with large 
coal reserves, such as Poland, it is more difficult to stop the exploitation of this energy source in favor of more environmentally friendly resources. Research carried by Ossowska and the research team [98] also shows that less developed countries are distinguished by lower greenhouse gas emissions (including Central and Eastern Europe countries), while GDP growth results in increased greenhouse gas emissions.

Beneficiaries may also obtain support for RES projects from the European Union, whose main objective consists in the transition to a low-carbon economy [101,102]. Rural areas exhibit significant potential for RES development, while municipalities, as the basic territorial self-government units in Poland, are the main creators of local development. The supply of electricity constitutes one of the basic tasks of the municipal economy. Due to the rising importance of this issue, it is becoming a cause for reflection around the world (e.g., $[103,104])$, while the degree of preparation of local authorities may constitute a key determinant of the effectiveness of RES projects [54].

The key factor for the development of RES seems to be an appropriate energy policy and financial support. Poland, due to the number of rural areas, has favorable conditions for RES development. However, there is a regional disparity, which is influenced by many factors. Particularly great interest in this type of project was observed among rural entities in Eastern Poland, especially in the Lubelskie Voivodeship. Significant interest in RES activities in this voivodeship was also confirmed by Gradziuk and Gradziuk [97]. As Kazak et al. [54] indicate, EU funds in the field of RES have different success rates in Poland and other Member States [105], e.g., the Baltic States [106], Romania [107] and Italy [108].

Investment projects concerning renewable energy sources are an opportunity to stimulate local development in peripheral rural areas (especially in Eastern Poland) affected by population ageing and depopulation cf. $[109,110]$. The renewable energy sector creates a variety of jobs in manufacturing, services and construction requiring a variety of qualifications and skills. Its development not only increases but also improves the quality of jobs in the industry. The research conducted by Wasiuta [111] shows that the development of RES is not only an opportunity for local communities to create jobs but also an opportunity for local government units to introduce various types of taxes. The existing diversity concerning the implementation of investment projects involving environmentally friendly forms of energy, cofinanced by the EU, is influenced by socioeconomic, financial and environmental conditions.

The projects in RES, cofinanced by the EU, are more frequently implemented by municipalities with a lower level of development, characterized by a lower level of entrepreneurship development and typical agricultural functions. On the one hand, it results from the potential for the development of RES in the area of the said municipalities (the availability of land) while on the other, it may be considered an attempt to specialize the area in activities that provide the possibility to dynamize the economic development of the municipality. Moreover, the research conducted by Gradziuk and Gradziuk [55] proved a great diversity in acquiring EU funds by municipalities on the example of Lubuskie Voivodeship. It was furthermore found that the value of investments in RES was significantly and negatively correlated with the level of GDP per capita. Kazak et al. [54] added that the allocation of EU funds was not directed at the most profitable parts of Poland in terms of renewable energy production. The importance of experience in acquiring EU support was further proved by Standar and Puslecki [88]. Furthermore it is easier to conduct proenvironmental activities in places where the area is still undeveloped. As Kazak et al. [54] note the density of development and the degree of dispersion of potential customers affect the size and economic impact of RES implementation.

\section{Conclusions}

The research revealed that 2777 projects in the field of energy have been conducted within the 2014-2020 Perspective, amounting to nearly PLN 13 billion (EUR 2.93 billion), of which approximately $75.8 \%$ has been financed from the EU budget. The most active beneficiaries are local self-government units and among them-municipalities, whose 
projects account for $95.1 \%$ of the total number and over $97 \%$ of the total value of projects implemented by the local self-government sector. In total, rural and urban-rural municipalities have implemented the highest number of RES projects. Interestingly, every fourth municipality conducts a minimum of two such projects, noticing high needs in this area. Statistically, solar energy-related activities were significantly more often undertaken, as confirmed by the Kruskal-Wallis test. These activities were characterized by high capital intensity. Up to date, half of them have been completed.

All projects are implemented by municipalities within the Regional Operational Programs, i.e., programs dedicated to the needs of beneficiaries from a particular region. Although each regional program includes actions aimed at the implementation of RES, the Kruskal-Wallis test proved the existence of a statistically significant spatial concentration of investment activity. Particularly great interest in this type of projects was observed among rural entities in Eastern Poland, especially in the Lubelskie Voivodeship.

In order to identify the main determinants of investment activity of rural and urbanrural municipalities in RES, a logit model was applied. It was used to determine the direction and strength of influence of individual factors on the activity of territorial units in acquiring projects in the area of environmentally friendly energy, cofinanced from the EU budget. The projects in RES, cofinanced by the EU, are more frequently implemented by municipalities with a lower level of development, characterized by a lower level of entrepreneurship development and typical agricultural functions. On the one hand, it results from the potential for the development of RES in the area of the said municipalities (the availability of land) while on the other, it may be considered an attempt to specialize the area in activities that provide the possibility to dynamize the economic development of the municipality.

The analyses determined that, among the financial factors, the level of municipality's own income potential, investment activity and the activity in the field of acquiring EU funds are important for their investment activity in obtaining RES projects and projects cofinanced from the EU funds. The lower own income potential of the RES project beneficiaries indicates a typically agricultural character of these municipalities (see [81]) and is associated with a lower level of development, as indicated above.

Additionally, the analyses proved a significant influence of the selected environmental factors on increasing the investment activity of the territorial units in the field of RES. The only positive impact on the investment activity of municipalities in such an area exhibited the share of wastelands in the total area of agricultural land. It indicates that it is easier to conduct proenvironmental activities in places where the area is still undeveloped.

Finally, it should be stated that empirical studies allowed for the positive verification of the research hypothesis, which assumed that "The highest investment activity in the field of local projects co-financed from EU funds, related to the development of RES in rural areas, may be attributed to municipalities performing primarily agricultural functions, located in Eastern Poland". The occurrence of significant disparities in the implementation of projects is not beneficial from the perspective of economic, social and territorial cohesion, and the achievement of sustainable development objectives. It should be emphasized that, for instance, the negative consequences on climate, do not have a territorial range of a particular municipality but rather involve them all, and only joint actions may stop them. Therefore, actions should be undertaken to persuade the remaining local self-government units about the importance and rightness of investments in RES.

Selection of the topic is appropriate due to the topicality of the issues and the great importance of renewable energy sources in the energy transformation. Moreover, the discussed topic is important from the economic point of view, based on the EU energy and climate policy and the resulting requirements to limit the use of conventional energy sources. Even during the last summit of EU leaders, the goals of energy policy were changed, which additionally proves the topicality of the article, even if it concerns one country (and 16 regions in the EU). However, empirical research covered by this paper does not exhaust all topics involved in the local government's investment activity related 
to RES in rural areas. Nevertheless, this paper brought more value to this research topic because such studies have not been conducted in other countries. The research methods used, and the analysis carried out on that basis, required the use of microdata for projects implemented by municipalities, Polish lowest-level LGUs. Often, it is impossible to access such data for other EU countries. Furthermore, the countries differ in the scope of public tasks carried out by local government units; this would make it difficult to directly compare the findings. However, the findings from this research are of particular importance to the objectives of the Polish regional-level energy policy. They also may provide an incentive and set a standard for scientists from other countries in order for them to conduct similar studies. The potential lines of future research could be indicated by an analysis of how advanced is the local government in using RES, what is the share of renewable energies in the local energy consumption and what is the impact of RES investments on local rural development.

Author Contributions: Conceptualization, A.K., A.S. and Ł.S.; data curation, A.K. and A.S.; formal analysis, A.K., A.S. and Ł.S.; methodology, A.K. and A.S.; project administration, A.K., A.S. and Ł.S.; resources, A.K., A.S. and Ł.S.; software, A.K. and A.S.; visualization, A.K. and A.S.; writingoriginal draft preparation, Ł.S., A.K. and A.S.; writing-review and editing, A.K., A.S. and Ł.S.; funding acquisition, A.K., A.S. and Ł.S.; investigation, A.K., A.S. and Ł.S.; supervision, A.K., A.S. and Ł.S.; validation, A.K., A.S. and Ł.S. All authors have read and agreed to the published version of the manuscript.

Funding: The research was cofinanced from resources of the Faculty of Economics Poznan University of Life Sciences and Faculty of Agriculture and Economics University of Agriculture in Krakow.

Institutional Review Board Statement: Not applicable.

Informed Consent Statement: Not applicable.

Data Availability Statement: Not applicable.

Conflicts of Interest: The authors declare no conflict of interest.

\section{References}

1. Haider, L.J.; Boonstra, W.J.; Peterson, G.D.; Schlüter, M. Traps and sustainable development in rural areas: A review. World Dev. 2018, 101, 311-321. [CrossRef]

2. Local Data Bank, Central Statistical Office, Warsaw, Poland. Available online: https://bdl.stat.gov.pl/BDL/dane/podgrup/temat (accessed on 1 September 2020).

3. Rosner, A.; Stanny, M. Socio-Economic Development of Rural Areas in Poland. The European Fund for the Development of Polish Villages Foundation; Institute of Rural and Agricultural Development, Polish Academy of Sciences: Warsaw, Poland, 2017.

4. Kozera, A.; Głowicka-Wołoszyn, R. Identification of functional types of rural communes in Poland. In Proceedings of the 2018 International Scientific Conference Economic Sciences for Agribusiness and Rural Economy, Warsaw, Poland, 7-8 June 2018; Gołębiewski, J., Ed.; Warsaw University of Life Sciences Press: Warsaw, Poland, 2018; pp. 109-115. [CrossRef]

5. Bański, J.; Mazur, M. Classification of rural areas in Poland as an instrument of territorial policy. Land Use Policy 2016, 54, 1-17. [CrossRef]

6. Bartkowiak, N. The diversity of socioeconomic development of rural areas in Poland in The Western Borderland and the problem of post-state farm localities. Oeconomia Copernic. 2017, 8, 417-431. [CrossRef]

7. Szymańska, D.; Chodkowska-Miszczuk, J. Endogenous resources utilization of rural areas in shaping sustainable development in Poland. Renew. Sustain. Energy Rev. 2011, 15, 1497-1501. [CrossRef]

8. Drejerska, N.; Gołębiewski, J. The role of Poland's primary sector in the development of the country's bioeconomy. Ital. Rev. Agric. Econ. 2017, 72, 311-326. [CrossRef]

9. Rural Development Programme for 2014-2020 (Program Rozwoju Obszarów Wiejskich na Lata 2014-2020); Ministerstwo Rozwoju Wsi i Rolnictwa: Warsaw, Poland. Available online: https:/ /www.gov.pl/web/rolnictwo/-program-rozwoju-obszarow-wiejskich-20 14-2020-prow-2014-2020 (accessed on 10 December 2020).

10. Akella, A.K.; Saini, R.P.; Sharma, M.P. Social, economical and environmental impacts of renewable energy systems. Renew. Energy 2009, 34, 390-396. [CrossRef]

11. Energy Law Act of 10 April 1997, Dz. U./Journal of Laws/of 2006, No. 89, Item. 625 as Amended (Ustawa z Dnia 10 Kwietnia 1997 Roku Prawo Energetyczne, Dz. U. z 2006 r., Nr 89, poz. 625 z późn. zm.). Available online: https:/ /isap.sejm.gov.pl/isap. nsf/download.xsp/WDU19970540348/U/D19970348Lj.pdf (accessed on 10 December 2020). 
12. Yang, J.; Li, X.; Peng, W.; Wagner, F.; Mauzerall, D.L. Climate, air quality and human health benefits of various solar photovoltaic deployment scenarios in China in 2030. Environ. Res. Lett. 2018, 13, 064002. [CrossRef]

13. Panwar, N.L.; Kaushik, S.C.; Kothari, S. Role of renewable energy sources in environmental protection: A review. Renew. Sustain. Energy Rev. 2011, 15, 1513-1524. [CrossRef]

14. York, R.; McGee, J.A. Understanding the Jevons paradox. Environ. Sociol. 2016, 2, 77-87. [CrossRef]

15. Alcott, B. Jevons' paradox. Ecol. Econ. 2005, 54, 9-21. [CrossRef]

16. Sorrell, S. Jevons' Paradox revisited: The evidence for backfire from improved energy efficiency. Energy Policy 2009, 37, 1456-1469. [CrossRef]

17. Dinda, S. Environmental Kuznets curve hypothesis: A survey. Ecol. Econ. 2004, 49, 431-455. [CrossRef]

18. Jebli, M.B.; Youssef, S.B. The environmental Kuznets curve, economic growth, renewable and non-renewable energy, and trade in Tunisia. Renew. Sustain. Energy Rev. 2015, 47, 173-185. [CrossRef]

19. Pieńkowski, D. Paradoks Jevons' a a konsumpcja energii w Unii Europejskiej (The Jevons Effect and the Consumption of Energy in the European Union). Probl. Ekorozw. Probl. Sustain. Dev. 2012, 7, 105-116.

20. Vavrek, R.; Chovancová, J. Energy Performance of the European Union Countries in Terms of Reaching the European Energy Union Objectives. Energies 2020, 13, 5317. [CrossRef]

21. EU COM. Communication from the Commission to the European Parliament, the Council, the European Economic and Social Committee and the Committee of the Regions A Roadmap for Moving to a Competitive Low Carbon Economy in 2050; European Commission (EU COM): Brussels, Belgium, 2011.

22. Klepacka, A. Significance of renewable energy sources in sustainable development. Ann. Pol. Assoc. Agric. Agribus. Econ. 2019, XXI, 55-64. [CrossRef]

23. An Official Website of the European Union. Available online: https://europa.eu/european-union/topics/environment_pl (accessed on 7 January 2021).

24. Piwowar, A.; Dzikuć, M. Development of renewable energy sources in the context of threats resulting from low-altitude emissions in rural areas in Poland: A review. Energies 2019, 12, 3558. [CrossRef]

25. Banaszewska, M.; Bischoff, I. The Political Economy of EU-funds: Evidence from Poland. Jahrb. Natl. Stat. 2017, 237, 191-224. [CrossRef]

26. Winzer, C. Conceptualizing energy security. Energy Policy 2012, 46, 36-48. [CrossRef]

27. Kruyt, B.; van Vuuren, D.P.; de Vries, H.J.; Groenenberg, H. Indicators for energy security. Energy Policy 2009, 37, $2166-2181$. [CrossRef]

28. Cullmann, A.; Nieswand, M.; Seifert, S.; Stiel, C. A (re) municipalization trend among energy utilities: Truth or myth? DIW Econ. Bull. 2016, 6, 227-232.

29. Berlo, K.; Wagner, O.; Heenen, M. The incumbents' conservation strategies in the German energy regime as an impediment to re-municipalization-An analysis guided by the multi-level perspective. Sustainability 2017, 9, 53. [CrossRef]

30. Brinker, L.; Satchwell, A.J. A comparative review of municipal energy business models in Germany, California, and Great Britain: Institutional context and forms of energy decentralization. Renew. Sustain. Energy Rev. 2020, 119, 109521. [CrossRef]

31. Voorn, B.; Van Genugten, M.L.; Van Thiel, S. Re-interpreting re-municipalization: Finding equilibrium. J. Econ. Policy Reform. 2020, 3, 1-14. [CrossRef]

32. Eberts, R.W.; Gronberg, T.J. Jurisdictional homogeneity and the Tiebout hypothesis. J. Urban Econ. 1981, 10, 227-239. [CrossRef]

33. Bölük, G.; Mert, M. Fossil \& renewable energy consumption, GHGs (greenhouse gases) and economic growth: Evidence from a panel of EU (European Union) countries. Energy 2014, 74, 439-446. [CrossRef]

34. Mardani, A.; Streimikiene, D.; Nilashi, M.; Arias Aranda, D.; Loganathan, N.; Jusoh, A. Energy consumption, economic growth, and $\mathrm{CO}_{2}$ emissions in G20 countries: Application of adaptive neuro-fuzzy inference system. Energies 2018, 11, 2771. [CrossRef]

35. Farhani, S.; Mrizak, S.; Chaibi, A.; Rault, C. The environmental Kuznets curve and sustainability: A panel data analysis. Energy Policy 2014, 71, 189-198. [CrossRef]

36. López-Menéndez, A.J.; Pérez, R.; Moreno, B. Environmental costs and renewable energy: Re-visiting the Environmental Kuznets Curve. J. Environ. Manag. 2014, 145, 368-373. [CrossRef]

37. Helm, D. The future of fossil fuels-Is it the end? Oxf. Rev. Econ. Policy 2016, 32, 191-205. [CrossRef]

38. Freire-González, J.; Puig-Ventosa, I. Energy efficiency policies and the Jevons paradox. Int. J. Energy Econ. Policy $2015,5,69$.

39. Copiello, S. Building energy efficiency: A research branch made of paradoxes. Renew. Sustain. Energy Rev. 2017, 69, 1064-1076. [CrossRef]

40. Dzikuć, M.; Kuryło, P.; Dudziak, R.; Szufa, S.; Dzikuć, M.; Godzisz, K. Selected Aspects of Combustion Optimization of Coal in Power Plants. Energies 2020, 13, 2208. [CrossRef]

41. Foxon, T.J. A coevolutionary framework for analysing a transition to a sustainable low carbon economy. Ecol. Econ. 2011, 70, 2258-2267. [CrossRef]

42. Gradziuk, P.; Gradziuk, B. Gospodarka niskoemisyjna-nowe wyzwanie dla gmin wiejskich. Wieś Rol. 2016, 1, 105-126. [CrossRef]

43. Owen, R.; Brennan, G.; Lyon, F. Enabling investment for the transition to a low carbon economy: Government policy to finance early stage green innovation. Curr. Opin. Environ. Sustain. 2018, 31, 137-145. [CrossRef]

44. Winkler, H.; Marquand, A. Changing development paths: From an energy-intensive to low-carbon economy in South Africa. Clim. Dev. 2009, 1, 47-65. [CrossRef] 
45. European Commission. Proposal for a Regulation of the European Parliament and of the Council on the Governance of the Energy Union, Amending Directive 94/22/EC, Directive 98/70/EC, Directive 2009/31/EC, Regulation (EC) No 663/2009, Regulation (EC) No 715/2009, Directive 2009/73/EC, Council Directive 2009/119/EC, Directive 2010/31/EU, Directive 2012/27/EU, Directive 2013/30/EU and Council Directive (EU) 2015/652 and Repealing Regulation (EU) No 525/2013: COM (2016) 759. Available online: https:/ / eur-lex.europa.eu/legal-content/EN/TXT/?uri=CELEX\%3A52016PC0759 (accessed on 1 January 2021).

46. Veum, K.; Bauknecht, D. How to reach the EU renewables target by 2030? An analysis of the governance framework. Energy Policy 2019, 127, 299-307. [CrossRef]

47. Marks-Bielska, R.; Bielski, S.; Pik, K.; Kurowska, K. The Importance of Renewable Energy Sources in Poland's Energy Mix. Energies 2020, 13, 4624. [CrossRef]

48. Ogarek, P. Przyszłość odnawialnych źródeł energii w Polsce w oparciu o Politykę Energetyczną Polski do 2040 roku (The future of renewable energy sources in Poland based on Poland's Energy Policy until 2040). In Bezpieczeństwo Energetyczne Polski i Europy Uwarunkowania-Wyzwania-Innowacje; Ruszel, M., Podmiotko, S., Eds.; Instytut Polityki Energetycznej im. I. Łukasiewicza: Rzeszów, Poland, 2019; pp. 98-119. Available online: https://www.instytutpe.pl/wp-content/uploads/2019/10/ Bezpieczeństwo-energetyczne-Polski-i-Europy-.pdf (accessed on 18 November 2020).

49. Ren, J.; Sovacool, B.K. Quantifying, measuring, and strategizing energy security: Determining the most meaningful dimensions and metrics. Energy 2014, 76, 838-849. [CrossRef]

50. Ang, B.W.; Choong, W.L.; Ng, T.S. Energy security: Definitions, dimensions and indexes. Renew. Sustain. Energy Rev. 2015, 42, 1077-1093. [CrossRef]

51. Azzuni, A.; Breyer, C. Definitions and dimensions of energy security: A literature review. Wiley Interdiscip. Rev. Energy Environ. 2018, 7, e268. [CrossRef]

52. Lucas, J.N.V.; Francés, G.E.; González, E.S.M. Energy security and renewable energy deployment in the EU: Liaisons Dangereuses or Virtuous Circle? Renew. Sustain. Energy Rev. 2016, 62, 1032-1046. [CrossRef]

53. Kosiński, E.; Trupkiewicz, M. Gmina jako podmiot systemu wspierania wytwarzania energii elektrycznej z odnawialnych źródeł energii (A municipality as a part of the suport system for generetion of electricity from renewable Energy sources). Ruch Praw. Ekon. Socjol. 2016, 78, 93-107.

54. Kazak, J.K.; Kamińska, J.A.; Madej, R.; Bochenkiewicz, M. Where Renewable Energy Sources Funds are Invested? Spatial Analysis of Energy Production Potential and Public Support. Energies 2020, 13, 5551. [CrossRef]

55. Gradziuk, P.; Gradziuk, B. Renewable energy sources as a development opportunity for peripheral areas/Odnawialne źródła energii szansą rozwojową obszarów peryferyjnych. Econ. Reg. Stud. 2020, 13, 184-198. [CrossRef]

56. Gradziuk, P.; Gradziuk, B.; Trocewicz, A.; Jendrzejewski, B. Potential of straw for energy purposes in Poland-Forecasts based on trend and causal models. Energies 2020, 13, 5054. [CrossRef]

57. Benedek, J.; Sebestyén, T.T.; Bartók, B. Evaluation of renewable energy sources in peripheral areas and renewable energy-based rural development. Renew. Sustain. Energy Rev. 2018, 90, 516-535. [CrossRef]

58. Bergmann, A.; Hanley, N.; Wright, R. Valuing the attributes of renewable energy investments. Energy Policy 2006, 34, 1004-1014. [CrossRef]

59. Waldenström, C.; Ferguson, R.; Sundberg, C.; Tidåker, P.; Westholm, E.; Åkerskog, A. Bioenergy from agriculture: Challenges for the rural development program in Sweden. Soc. Nat. Resour. 2016, 29, 1467-1482. [CrossRef]

60. Chodkowska-Miszczuk, J. Odnawialne źródła energii i ich wykorzystanie jako nowe trendy na obszarach wiejskich w Polsce. Studia Obsz. Wiej. 2014, 35, 227-241.

61. Poggi, F.; Firmino, A.; Amado, M. Planning renewable energy in rural areas: Impacts on occupation and land use. Energy 2018, 155, 630-640. [CrossRef]

62. Chodkowska-Miszczuk, J.; Biegańska, J.; Środa-Murawska, S.; Grzelak-Kostulska, E.; Rogatka, K. European Union funds in the development of renewable energy sources in Poland in the context of the cohesion policy. Energy Environ. 2016, 27, 713-725. [CrossRef]

63. Kaya, O.; Klepacka, A.M.; Florkowski, W.J. Achieving renewable energy, climate, and air quality policy goals: Rural residential investment in solar panel. J. Environ. Manag. 2019, 248, 109309. [CrossRef] [PubMed]

64. Hernik, J.; Noszczyk, T.; Rutkowska, A. Towards a better understanding of the variables that influence renewable energy sources in eastern Poland. J. Clean. Prod. 2019, 241, 118075. [CrossRef]

65. Štreimikiene, D. Review of financial support from EU Structural Funds to sustainable energy in Baltic States. Renew. Sustain. Energy Rev. 2016, 58, 1027-1038. [CrossRef]

66. Database of Implemented EU Projects; Ministry of Development Funds and Regional Policy: Warsaw, Poland. Available online: https:/ / www.funduszeeuropejskie.gov.pl/strony/o-funduszach/projekty/lista-projektow /lista-projektow-realizowanychz-funduszy-europejskich-w-polsce-w-latach-2014-2020/ (accessed on 22 September 2020).

67. Archive of Medium Courses; National Bank of Poland: Warsaw, Poland; Available online: https://www.nbp.pl/home.aspx?f= / kursy/arch_a.html (accessed on 19 December 2020).

68. Hosmer, D.W.; Lemeshow, S. Applied Logistic Regression; Wiley \& Sons: New York, NY, USA, 2000.

69. Stanisz, A. Przystępny Kurs Statystyki z Zastosowaniem Statistica PL na Przykładach z Medycyny, tom 2, Modele Liniowe i Nieliniowe; Wydawnictwo StatSoft Polska: Kraków, Poland, 2007.

70. Hilbe, J.M. Logistic Regression Models; Chapman \& Hall/CRC Press: Boca Raton, FL, USA, 2009. 
71. Kleinbaum, D.G.; Klein, M. Logistic Regression; Springer: New York, NY, USA, 2002.

72. Cramer, J.S. Logit Models from Economics and Other Fields; Cambridge University Press: Cambridge, UK, 2011.

73. Maddala, G.S. Introduction to Econometrics, 3rd ed.; Wiley and Sons Ltd.: Chichester, UK; New York, NY, USA, 2001.

74. Bewick, V.; Cheek, L.; Ball, J. Statistics review 14: Logistic regression. Crit. Care 2005, 9, 112-118. [CrossRef] [PubMed]

75. Fierek, D.; Janiszewska, D. Lokalne uwarunkowania województwa pomorskiego dla produkcji biogazu (Local Determinants of Pomorskie Voivodeship for Biogas Production). Zesz. Nauk. Wydziału Nauk Ekon. 2016, 20, 69-81.

76. Bartkowiak-Bakun, N.; Standar, A. Ocena Oddziatywania Wybranych Działań PROW 2007-2013 na Zrównoważony Rozwój Obszarów Wiejskich Polski: (Analiza Regionalna) (Assessment of the Impact of Selected RDP 2007-2013 on the Sustainable Development of Polish Rural Areas: (Regional Analysis); Wydawnictwo Uniwersytetu Przyrodniczego w Poznaniu: Poznań, Poland, 2015.

77. Bartkowiak, N.; Poczta, W. Czynniki Rozwoju Obszarów Wiejskich Wielkopolski (Development Factors of Rural Areas of Wielkopolska); Wydawnictwo Uniwersytetu Przyrodniczego w Poznaniu: Poznań, Poland, 2015.

78. Standar, A. Assessing the Scale of and Financial Reasons behind Differences in the Local Government Units' Investment Expenditures in the Context of Reducing Disparities in Socio-Economic Development. In International Scientific Days 2018. "Towards Productive, Sustainable and Resilient Global Agriculture and Food Systems": Conference Proceedings; Horská, E., Kapsdorferová, Z., Hallová, M., Eds.; Wolters Kluwer ČR: Prague, Czech Republic, 2018; pp. 1462-1475.

79. Głowicka-Wołoszyn, R.; Kozera, A.; Wysocki, F. Identyfikacja wewnętrznych uwarunkowań samodzielności i atrakcyjności finansowej gmin wiejskich województwa wielkopolskiego z wykorzystaniem biplotu (Internal Determinants Identification of the Autonomy and Financial Attractiveness of Rural Gminas in Wielkopolskie Voivodship Using Biplot). Wiadomości Stat. 2017, 8,74-84.

80. Energy from Renewable Sources in 2018; Central Statistical Office: Warsaw, Poland, 2019.

81. Fact Sheets on the European Union, European Parliament. Available online: https:/ /www.europarl.europa.eu/factsheets/pl/ sheet/68/polityka-energetyczna-zasady-ogolne (accessed on 5 December 2020).

82. Marks-Bielska, R.; Bielski, S.; Novikova, A.; Romaneckas, K. Straw stocks as a source of renewable energy. A case study of a district in Poland. Sustainability 2019, 11, 4714. [CrossRef]

83. Robles, R.; Dalia, P. Interactions between agriculture and energy policies: The case of Castile and Leon (Spain). Rural Dev. 2011, 5, 222-228.

84. Wielkopolski Regionalny Program Operacyjny 2014-2020; Zarząd Województwa Wielkopolskiego: Poznań, Poland, 2015.

85. Indicators for the Evaluation of the Financial Position of Territorial Self-Government Units in 2016-2018 (Wskazniki do Oceny Sytuacji Finansowej JST w Latach 2016-2018); Ministry of Finance: Warsaw, Poland, 2019. Available online: https://www.gov.pl/ web / finanse/wskazniki-do-oceny-sytuacji-finansowej-jednostek-samorzadu-terytorialnego-w-latach-2016-2018 (accessed on 22 October 2020).

86. Satola, L. Kapitał ludzki źródłem przewagi konkurencyjnej gmin w aspekcie rozwoju lokalnego (Human capital as a source of competitive advantage of communes in the context of local government). Rocz. Nauk. Stowarzyszenia Ekon. Rol. Agrobiz. 2009, 11, 293-298.

87. Satoła, Ł.; Standar, A.; Kozera, A. Financial autonomy of local government units: Evidence from Polish rural municipalities. Lex Localis Local Self-Gov. 2019, 17, 321-342. [CrossRef]

88. Standar, A.; Puślecki, Z.W. Ocena Zastosowania Środków Polityki Regionalnej Unii Europejskiej Przez Samorządy Gminne Województwa Wielkopolskiego; Wydawnictwo Uniwersytetu Przyrodniczego w Poznaniu: Poznań, Poland, 2011.

89. EU Strategy for the Baltic Sea Region (Strategia UE dla regionu Morza Bałtyckiego), Komisja Wspólnot Europejskich, Bruksela. 2009. Available online: https://www.gov.pl/web/gospodarkamorska/strategia-ue-dla-regionu-morza-baltyckiego (accessed on 7 December 2020).

90. Europe 2020 A Strategy for Smart, Sustainable and Inclusive Growth; European Commission: Brussels, Belgium, 2010. Available online: https: / / eur-lex.europa.eu/legal-content/en/ALL/?uri=CELEX\%3A52010DC2020 (accessed on 7 December 2020).

91. The Energy Policy of Poland Until 2030 (Polityka Energetyczna Polski do 2030 Roku); Ministerstwo Gospodarki: Warsaw, Poland, 2009. Available online: https://www.gov.pl/web/klimat/polityka-energetyczna-polski-do-2030-roku (accessed on 7 December 2020).

92. The Energy Security and Environment Strategy (Strategia Bezpieczeństwo Energetyczne i Środowisko z Perspektywa do 2020). Uchwała Rady Ministrów z Dnia 15 Kwietnia 2014 r. (M.P. z 2014, poz. 469). Available online: http:/ /isap.sejm.gov.pl/isap.nsf/ DocDetails.xsp?id=wmp20140000469 (accessed on 7 December 2020).

93. The Transport Development Strategy Until 2020 (with a Perspective Until 2030) (Strategia Rozwoju Transportu do 2020 roku (z Perspektywą do 2030 Roku)). Załącznik do Uchwały nr 58 Rady Ministrów z Dnia 15 Kwietnia 2014 r. Available online: https:/ / www.gov.pl/documents/905843/1047987/Strategia_Rozwoju_Transportu_do_2020_roku.pdf/ead3114a-aac7-3 cdd-c71d-7f88267ce596 (accessed on 7 December 2020).

94. National Energy Efficiency Action Plan for Poland (Krajowy Plan Działań Dotyczacy Efektywności Energetycznej dla Polski); Ministerstwo Energii: Warsaw, Poland, 2017. Available online: https:/ /www.gov.pl/web/klimat/krajowy-plan-dzialan-dotyczacyefektywnosci-energetycznej (accessed on 7 December 2020).

95. The National Renewable Energy Action Plan (Krajowy Plan Działań w Zakresie Odnawialnych Źródeł Energii); Ministerstwo Gospodarki: Warsaw, Poland, 2010. Available online: https://www.senat.gov.pl/gfx/senat/userfiles/_public/k7/komisje/2011/kgn/288/28 8-1.pdf (accessed on 7 December 2020). 
96. Partnership Agreement-Programming of the 2014-2020 Financial Perspective (Umowa Partnerstwa. Programowanie Perspektywy Finansowej 2014-2020); Ministerstwo Rozwoju i Inwestycji: Warsaw, Poland, 2014. Available online: https://www.funduszeeuropejskie. gov.pl/strony/o-funduszach/dokumenty/umowa-partnerstwa/ (accessed on 7 December 2020).

97. Gradziuk, P.; Gradziuk, B. Próba oceny efektów absorpcji środków z funduszy europejskich na rozwój wykorzystania odnawialnych źródeł energii w województwie lubelskim. Rocz. Nauk. Ekon. Rol. I Rozw. Obsz. Wiej. 2017, 104, 95-105. [CrossRef]

98. Ossowska, L.; Janiszewska, D.; Bartkowiak-Bakun, N.; Kwiatkowski, G. Energy Consumption Versus Greenhouse Gas Emissions in EU. Eur. Res. Stud. J. 2020, XXIII, 185-198. [CrossRef]

99. Fischer, S. The EU's new energy and climate: Policy framework for 2030. SWP Comments 2014, 55, 1-8.

100. Ringel, M.; Knodt, M. The governance of the European Energy Union: Efficiency, effectiveness and acceptance of the Winter Package 2016. Energy Policy 2018, 112, 209-220. [CrossRef]

101. Martí-Ballester, C.P. Do European renewable energy mutual funds foster the transition to a low-carbon economy? Renew. Energy 2019, 143, 1299-1309. [CrossRef]

102. Kachniarz, M.; Szewranski, S.; Kazak, J. The Use of European Funds in Polish and Czech Municipalities. A Study of the Lower Silesia Voivodship and Hradec Kralove Region. In IOP Conference Series: Materials Science and Engineering; IOP Publishing: Bristol, UK, 2019; Volume 471, p. 112047.

103. Ghiani, E.; Giordano, A.; Nieddu, A.; Rosetti, L.; Pilo, F. Planning of a Smart Local Energy Community: The Case of Berchidda Municipality (Italy). Energies 2019, 12, 4629. [CrossRef]

104. Malinauskaite, J.; Jouhara, H.; Egilegor, B.; Al-Mansour, F.; Ahmad, L.; Pusnik, M. Energy efficiency in the industrial sector in the EU, Slovenia, and Spain. Energy 2020, 208, 118398. [CrossRef]

105. Bointner, R.; Pezzutto, S.; Grilli, G.; Sparber, W. Financing innovations for the renewable energy transition in Europe. Energies 2016, 9, 990. [CrossRef]

106. Streimikiene, D.; Klevas, V.; Bubeliene, J. Use of EU structural funds for sustainable energy development in new EU member states. Renew. Sustain. Energy Rev. 2007, 11, 1167-1187. [CrossRef]

107. Bostan, I.; Lazar, C.M.; Asalos, N.; Munteanu, I.; Horga, G.M. The three-dimensional impact of the absorption effects of European funds on the competitiveness of the SMEs from the Danube Delta. Ind. Crops Prod. 2019, 132, 460-467. [CrossRef]

108. Carfora, A.; Romano, A.A.; Ronghi, M.; Scandurra, G. Renewable generation across Italian regions: Spillover effects and effectiveness of European Regional Fund. Energy Policy 2017, 102. [CrossRef]

109. Żmija, K.; Fortes, A.; Tia, M.N.; Šūmane, S.; Ayambila, S.N.; Żmija, D.; Satoła, Ł.; Sutherland, L.A. Small farming and generational renewal in the context of food security challenges. Glob. Food Secur. 2020, 26, 100412. [CrossRef]

110. Satoła, Ł. Problems of the aging of the farmers' population in small farms in Poland. Scientific Papers Series-Management. Econ. Eng. Agric. Rural Dev. 2019, 19, 305-310.

111. Wasiuta, A. Renewable energy sources and their impact on Polish labor market in the context of global energy problems. In International Scientific Days 2018. Towards Productive, Sustainable and Resilient Global Agriculture and Food Systems; Horská, E., Kapsdorferová, Z., Hallová, M., Eds.; Wolters Kluwer ČR: Prague, Czech Republic, 2018; pp. 2726-2737. Available online: http:/ /spu.fem.uniag.sk/mvd2018/isd2018_proceedings/isd_conference_proceedings.pdf (accessed on 5 January 2021). 